\title{
Early Postpartum Hemorrhage
}

National Cancer Institute

\section{Source}

National Cancer Institute. Early Postpartum Hemorrhage. NCI Thesaurus. Code C114375.

Cumulative blood loss of greater than or equal to $1000 \mathrm{ML}$ or blood loss accompanied by signs or symptoms of hypovolemia within 24 hours following the birth process (includes intrapartum loss). (reVITALize) 